\title{
The Political Economy of Capital Flight: Governance Quality and Capital Flight in the East Africa Community
}

\author{
Zerayehu Sime Eshete \\ $\mathrm{PhD}$ in Economics, Addis Ababa University, Department of Economics
}

\begin{abstract}
This paper examines the impacts of political economy factors on an illicit capital outflow in the East African Community using robust panel data models. The main findings of the study are as follows: An increase in Gross Domestic Product is a statistically significant variable and reduces an illicit flow of illegal capital outflow from the Community. However, foreign direct investment, total grant and exchange rate statistically significant and aggravate the outflow of capital. This is due to poor governance and economic policies that governments favor foreign investors over local investors. An aggregate index of poor regulatory quality and government ineffectiveness, state fragile index, and the political instability index are statistically significant and positively influence an illicit capital flight from the Community. However, the existed perceived corruption level does not positively contribute to capital flight, but an intensive corruption level positively influences capital flight overtime, bringing a mixed sign of negative and positive depending on the level of corruption that affects capital flight overtime in the Community. The study, therefore, recommends that member countries in the Community need to undertake an effective governance and regulatory qualities, political stability and controlling power of corruption in order to control capital flight.
\end{abstract}

Keywords: Capital flight, governance quality, political stability index, regulatory quality index, Government Effectiveness, Control of Corruption, World Bank Residual Methods

DOI: $10.7176 / \mathrm{JESD} / 10-11-02$

Publication date:June $30^{\text {th }} 2019$

\section{Introduction}

The East African Community that comprises the Burundi, Kenya, Rwanda, Tanzania and Uganda was formerly found in 1967 and latterly revived in 2000 with the objective of Political Federation. The Community has already experienced a common market for capital, labor, goods and service since 2010 as stated under Article 5 (2) of the Treaty. As a result of such integration, the trade performance in the community grew by $40 \%$ in $2005-2009$. The Ugandan and Tanzanian exports to Kenya increased tenfold and triple in 2009, respectively. The 2010 treaty among partners highly enhanced the intra-trade in the community. The remarkable performance of the trade is also complemented by cross-border investment in the service sector. In a nutshell, the economic performance in the community attracts the attentions of development partners as the aggregate GDP increased to USD 75 billion in 2009 from USD 30 Billion in 2002. Nonetheless, the intra-GDP growth rate remains uneven (EAC, 2011). As a result of sustained economic growth, members of the community progress their achievements in terms of reducing poverty, child mortality and enhancing universal primary education (Catherine et al., 2012). The existence of developed capital market by mobilizing saving and investment is a compulsory requirement in order to lift up and sustain the ongoing remarkable performance of the Community. The Community in this regard made an interesting progress through eliminating constraints on capital transactions across the Community. However, resource mobilization and capital formation face a daunting challenge due to many reasons. One of the main causative factors that weaken capital formation and resource mobilization is an illegal capital flight from the Community. Though adequate attention paid to capital flight, it still remains a critical problem and adversely affects the economic performance of the Community (Boyrie, 2010).

The Africa Progress Panel Report 2013 shows that the capital flight in Africa exceeds investment in 20082010. The East African Community (EAC) has lost USD 1.2 billion in 2000-2008 in aggregate, showing that capital flight is a chronic problem. It weakens not only capital formation, but also it causes economic slowdown, leading to a sluggish rate of regional integration and productivity capacity of member countries. The existence of sizable illicit capital flight puts on adverse effects on the performance of the economy. It makes the financial sector to lose potential resource and negatively affect the balance of payment as well as develop rent-seeking behaviors. These place persistent adverse effects on development program of the Community as an illegal capital flight weakens the domestic asset of the African countries (Abdilahi and Bernard, 2011).

EAC Next to Nigeria, the EAC is one of the fastest growing regions in the world in terms of economic growth rate and MDG targets. The Community is expected to be the second largest market in Africa in the recent future, so that investors are attracted to the regions in order to access the envisaged benefit. In addition to the existing liberal African economies, it is also characterized by economic and political stability that lays a fertile ground for capital investment, claiming prudent capital market and sound regulatory system for managing capital formation. Most research papers have highly paid attentions for economic factors that cause capital flight as they consider 
capital flight as a portfolio choice. This is in response of discouraging investment climate that bears uncertainty and risks associated with investment rate of return (Collier et al., 2001 and Sheets, 1995). However, institutional factors like constraints on power exercising, poor governance and lack of political confidence receive a special attention in search of sustainable growth nowadays as economic and political elites distort the system of economy in general and capital market in particular (Acemoglu et al., 2003 and Dornbusch, 1990). If this problem is not solved shortly, the consequences will not able to be confined within capital market only. It rather negatively affects and spreads to the regional integration and development program of the Community. Therefore, the overriding objective of the study will be to specify, estimate and analyze the political, economic and institutional factors that are responsible for capital flight in the East African Community. The study has the following specific objectives to examine political economy and institutional factors that explain capital flight in East African Community member countries, and to devise strategies for curbing capital flight based on the key determinants of capital flight using a robust panel data model. The outcomes of the study will also be relevant for policy prescriptions on which the concerned bodies can design tackling strategies in order to address an illegal capital flight from the Community.

\section{Governance and Capital Flight in East Africa Community}

In Sub-Saharan Africa region, the amount of the outflow of capital was projected around USD 24.7 billion, which accounts for 7.5 percent of their aggregate GDP, in 1990-2005. The EAC also has a significant share in this regard. For instance, according to the data estimated by the Global Financial Security for the period 2000-2008, the EAC has lost USD 1.2 billion, on average, in the form of capital flight, of which Uganda accounts for USD 429 million, Kenya USD 205 million, Tanzania USD 367 million, Burundi USD 49 million, and Rwanda USD 95 million on average. In terms of cumulative capital flight, the African LDCs accounts for 69 percent of total capital outflow from the world LDCs, followed by Asia (29 percent) and Latin America ( 2 percent). This approximate to US\$197 billion flowed out of the 48 poorest developing countries. Out of which, the total capital outflow from Uganda is USD 8.8 billion that makes the country categorized within the top ten LDC countries that illegally export capital in 1990-2008. Tanzania also lost USD 2.3 billion, Rwanda USD 1.6 billion, and Burundi USD 969 million in the same reference period.

Moreover, most influential investors and politician are suspected to siphon off domestic money into offshore tax haven and developed countries out of the poorer countries. For instance, the EAC countries have lost USD 1.3 billion in terms of tax havens in Swiss banks, of which Kenya accounts for USD 857 million. Next to Kenya, Tanzania accounts for USD 178 million, followed by Uganda USD 159 and Rwanda 29.7 million. Burundi however accounts for USD 16.7 million capital flight from EAC and deposited in the Swiss banks (http://www.theeastafrican.co.ke).

On top of this bad performance of capital formation, the worldwide governance indicators indicate the existence of poor governance as measured with six dimensions of governance. All indicators reflect how the people perceive towards each dimension. Note that the estimate of governance ranges from approximately -2.5 (weak) to 2.5 (strong) governance performance.

Table 1: - The Worldwide Governance Indicators in 2012

\begin{tabular}{|l|r|r|r|r|r|r|}
\hline \multirow{2}{*}{$\begin{array}{c}\text { Member } \\
\text { Countries }\end{array}$} & $\begin{array}{c}\text { Toice and } \\
\text { Accountabil } \\
\text { ity }\end{array}$ & $\begin{array}{c}\text { Political Stability } \\
\text { and Absence of } \\
\text { Violence/Terroris } \\
\mathrm{m}\end{array}$ & $\begin{array}{c}\text { Governme } \\
\text { nt } \\
\text { Effectiven } \\
\text { ess }\end{array}$ & $\begin{array}{c}\text { Regulatory } \\
\text { Quality }\end{array}$ & $\begin{array}{c}\text { Rule of } \\
\text { Law }\end{array}$ & $\begin{array}{c}\text { Control of } \\
\text { Corruption }\end{array}$ \\
\hline Burundi & -0.93 & -1.68 & -1.33 & -0.96 & -1.09 & -1.46 \\
\hline Kenya & -0.30 & -1.29 & -0.55 & -0.31 & -0.87 & -1.10 \\
\hline Rwanda & -1.24 & -0.21 & -0.06 & -0.10 & -0.26 & 0.66 \\
\hline Tanzania & -0.22 & -0.03 & -0.69 & -0.40 & -0.58 & -0.85 \\
\hline Uganda & -0.49 & -0.89 & -0.57 & -0.24 & -0.36 & -0.95 \\
\hline
\end{tabular}

Source: - World Bank, www.govindicators.org

The community economic performance is challenged by capital flight and poor governance. These slow down the partner countries' efforts to reach their expected outcomes of regional integration and intensify economic stagnation in the long run in terms of balance of payment disequilibria, poverty, deteriorating government finances, increasing macroeconomic and political instability (collier, 2006). Moreover, a significant outflow of capital from the community also forces the governments to borrow in a continuous way, leading to high debt burden, shortage of foreign currency reserve and exchange rate fluctuation. It also adversely affects the investment climate and infrastructural development that contribute much towards Community integration. The structural and institutional developments are also affected by the illegal capital outflow as the economic and political elites take their own advantage at the cost of the country, negatively impacts on wealth distribution (Epstein 2005). On the other side, by the time economic and political elites lose their confidence over capital they hold, the ensuing capital flight causes higher interest rate and exchange rate depreciation as there is a shortage of loanable fund and foreign 
currency reserve, respectively. If the problem is not treated wisely, it could bring currency crash, skyrocket interest rates, bad foreign debt and macroeconomic disruption. These all consequences could slow investment and thereby capital formation, putting a negative repercussion on the rate of economic growth.

\section{Theoretical Framework}

Capital flight is an illegal outflow of capital from a given country in terms of trade mispricing (under invoicing export bill and over invoicing import bill), smuggling goods, antiques, precious metal, cash movements, bribery in the form of corruption in various deals and swap arrangements, bank transfers and the like (Bhagwati, 1964; Cerven, 2006 and Schneider, 2001). Understanding the broad definition of capital flight, there are two basic theoretical framework of conceptualizing capital flight: - economic framework and institutional framework.

In the economic framework, many scholars consider four dimensions and hypotheses in order to conceptualize the causative factors of capital flight. The first one is a portfolio choice framework that pays more attention to the incentives of relative risk diversification and return differential as triggering factors for an illegal outflow of capital (Ajayi, 1992). However, the second framework, which is called an investment diversion thesis, focuses on diversion of investment towards a more stable economic and political condition in developed countries. This is due to the existence of political and macroeconomic risk in a given country that have worst investment opportunities (Forgham, 2008). Moreover, the third framework in light of debt-driven flight thesis or debt overhang thesis proposes that capital flight is highly intensified with the existence of heavy external debt. The intuition behind heavy debt is that the ensuing problems of devaluation, fiscal crisis, crowding out and expropriation of assets to pay for the foreign debt fuels up capital flight. It entails further borrowing and foreign dependency. The last framework is a Tax-Depressing Thesis. It postulates that an illegal outflow of capital leads to loss of tax revenue, which in turn reduces debt service and further accumulates debt burden (Ajayi, 1992). In a nutshell, external borrowing and debt (Ndikumana and Boyce, 2003), evolution of capital flight (Cerra et al., 2008 and Nyoni, 2000), inflation (Dooley, 1988), economic growth (Morgan Guaranty, 1988), financial development (Ndikumana and Boyce, 2003 and Collier et al., 2001), black market premium (Collier, Hoeffler, and Pattillo, 2004) are likely the determinants of capital flight.

In the institutional framework, more weight is given to institutional factors that triggering capital flight such as constraints on the power of the enforcement and political confidence of elites (Acemoglu et al., 2003 and Dornbusch, 1990). The lack of strong institutional system and good governance expose elites to corrupt the capital market at the cost of the national interest (Ndikumana and Boyce, 2003). As a result, poor institutional quality including weak democracy and political freedom aggravates an illegal outflow of capital from poor countries, diverting scarce resource from injecting the development pipeline (Lensink et al., 2000). Political instability and conflict also attribute a negative repercussion to capital market and induce residents to move their assets out of the country as they fear the volatile political situation that increase risk of losing rate of return on domestic assets (Ndiaye, 2009). Moreover, by the time they do not have trust on the certainty of government policy overtime; residents choose to make a decision of moving their assets out country as they experienced variability in interest rate, tax rate and fiscal deficit (Hermes and Lensik, 2001).

\section{Model Specification for Capital Flight and Estimation Technique}

Model specification for capital flight considers assumptions, style of estimation techniques and level of development of a given country. Both theoretical and empirical literatures suggest the potential factors that are responsible for an illegal outflow of capital are economic factors and governance quality factors. The study considers inflation, GDP, FDI, total grants, fiscal deficit and foreign exchange rate as the major economic determinants of capital flight in EAC. On top of these economic factors, it also incorporates corruption indices, regulator quality, government effectiveness, political instability, and state fragmentation index as the major factors that explain governance quality. This specification of the capital flight model is supported by the research papers conducted by Dooley (1988), Ndikumana and Boyce (2003), Cerra et al. (2008), Nyoni (2000), Collier, Hoeffler and Pattillo (2004), Seung, (2010) and Thomas (2010).

The final model of capital flight, therefore, is presented below:

$$
\begin{aligned}
& K F_{i t}=\beta_{0}+\beta_{1} I N F_{t i}+\beta_{2} G D P_{i t}+\beta_{3} F D I_{i t}+\beta_{4} T G_{i t}+\beta_{5} F X_{i t}+\beta_{6} C P C_{i t}+\beta_{7}(C P C)^{2}+
\end{aligned}
$$

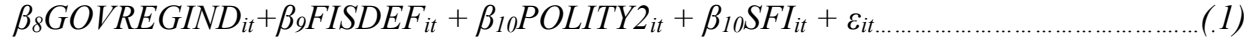

Where $\mathrm{KF}=$ Capital Flight, GDP $=$ Gross Domestic Product, FDI= Foreign Direct Investment, $\mathrm{TG}=$ Total Grant including technical support, $\mathrm{FX}=$ Official Exchange Rate, $\mathrm{CPC}=$ Corruption Index, $\mathrm{CPC}^{2}=$ Intensity of Corruption Index, GOVREGIND=Aggregated Index of Government Effectiveness and Regulatory Quality, FISDEF= Fiscal Deficit, POLITY2 $=$ Political Instability Index, SFI $=$ State Fragility Index, and $\varepsilon=$ the error term.

Based on the theoretical and empirical evidences, foreign resources (foreign grant and FDI) positively influence capital flight as the government provides favorable policy to foreign investors over local investors, forcing the domestic investors to move out their money. Otherwise, the inflow of foreign resources has a negative relationship with capital flight if there is the attractive investment climate. On the same note, if the government 
utilizes aid effectively, it reduces capital outflow. If not, capital flight increases over time. Regarding GDP, when the economy grows higher, it is an incentive to domestic investors so that they prefer to invest home, reducing capital flight. This indicates there is a negative relationship between GDP and capital flight. The higher official exchange rate positively affects capital flight as domestic currency is devalued and the relationship between fiscal deficit and capital flight is also positive as deficit leads to a higher tax. Regarding governance quality indicators, all of them (poor government and regulatory index, higher corruption index, state fragile index and political instability aggravates an illegal outflow of capital from domestic economy. In a nutshell, it is only foreign resource that has a mixed impact on capital flight, depending on the utilization capacity of the economy and discriminatory policies. Note that all data are available from WB, IMF, UNCATAD, Global Report 2011 and Plity- 4 Project (Annex 1).

As the study considers the five members of the EAC, panel data modelling is appropriate in order to capture the heterogeneity and country-specific nature of the determinants of capital flight. The panel model controls the effects of unobserved variables of complexity of each country, namely- business practices, policies, regulations, social and the like country heterogeneity. However, it is not possible to use dynamic panel data model as the number of cross section does not exceed the number of years, $\mathrm{N}<\mathrm{T}$. The paper therefore employs a static panel date model of fixed effects and random effect.

The Fixed Effect model can be estimated by Within-group method, First Difference Method, and Least Square Dummy Variable (LSDV) method. The first two methods eliminate time-invariant characteristics and heterogeneity character of cross-sections so that they enable us to examine the net effect of explanatory variables that vary over time. However, the LSDV method introduces dummy variables for each cross-section in order to capture heterogeneity of each country. In summary, the assumption of Fixed Effect model is that all time-invariant characteristics of one country must not be correlated with characteristics of other country, error terms and individual characteristics are not correlated across countries. The specification of Fixed Effect model is presented as follows. The general form of panel data model is defined in equation 2

$Y_{i t}=\beta_{0}+\beta_{1} x_{i t}+\alpha_{i}+\varepsilon_{i t}$

$\varepsilon \quad$ Where $\mathrm{Y}$ is dependent variable, $\mathrm{X}$ is explanatory variables, $\alpha$ is country-specific explanatory variables or

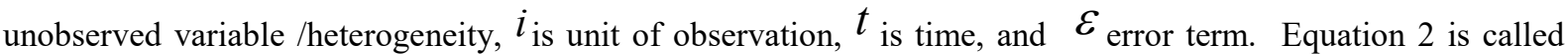
pooled or reference regression model. It is also possible to reformulate equation 2 in terms of the mean value of each variable within the group for each country in order to catch up the long run time effect in the model, it is said to be Between or Time Effect model.

$\overline{Y_{i}}=\beta_{0}+\beta_{1} \bar{x}_{i}+\alpha_{i}+\varepsilon_{i}$

Note that $\alpha_{i}$ is an unaffected as it has unique characteristics to each country over time remain the same overtime. The coefficient in equation indicates the long run impact of explanatory variables on outcome variable. Subtracting equation 2 from equation 1 gives Fixed Effect within Group Model that capture individual effect as follows.

$Y_{i t}-\overline{y_{i}}=\beta_{1}\left(x_{i t}-\overline{x_{i}}\right)+\left(\varepsilon_{i t}-\overline{\varepsilon_{i}}\right)$

The coefficients in this regards measure the impact of variation in explanatory variable on the variation of outcome variable, indicating the short run impact. The other method, on the other hand, proposes the first difference method by taking one lag period of equation 2 , and gives the following equation.

$Y_{i t-1}=\beta_{0}+\beta_{1} x_{i t-1}+\alpha_{i}+\varepsilon_{i t-1}$

Note that the lag value of Error! Bookmark not defined.is the same to the level value as it is time invariant variable. Subtracting equation 5 from equation 2 gives us First Difference Method of Fixed Effect Mode

$$
\left(Y_{i t}-Y_{i t-1}\right)=\beta_{0}+\beta_{1}\left(x_{i t}-x_{i t-1}\right)+\left(\varepsilon_{i t}-\varepsilon_{i t-1}\right)
$$

In equation 6 , the trend component is removed and there may have an autocorrelation problem as the error terms are correlated with each other in terms of the MA or AR process. Both equations 4 and 6 exclude the unobserved and heterogeneity variables out of the specification of panel model. The third Fixed Effect method of LSDV, however, addresses this flaw and introduces dummy variables for each country in order to capture country-specific characteristics. Equation 2 in this regard can be rewritten as in the following way.

$Y_{i t}=\beta_{0}+\beta_{1} x_{i t}+\alpha_{i} D_{i}+\varepsilon_{i t}$

Where $\alpha_{i} D_{i}$ is dummy variable for each country, $\alpha_{i} D_{i=1}$ if an individual country has a particular characteristics, and $\alpha_{i} D_{i=0}$, otherwise. The unobserved effect is now being treated as the coefficient of the individual-specific 
dummy variable. Note that if we include a dummy variable for every individual in the sample, we will fall into the dummy variable trap. To avoid this, we could define one individual to be the reference category, so that $\beta_{0}$ is its intercept, and then treat the $\mathrm{D}_{i}$ as the shifts in the intercept for the other individuals. However, the choice of reference category is often arbitrary. Alternatively, we can drop the $\beta_{0}$ intercept and define dummy variables for all of the individuals. In the entire Fixed Effect model, the error terms are not correlated by assumption. However, if they are correlated, the Fixed Effect model is not useful, leading to incorrect inference. Therefore, Random Effect model can be used for treating the situation where error terms are correlated. Contrary to Fixed Effect models, variations across countries are also considered as random and uncorrelated with explanatory variables so that such variation across countries (time invariant variables) is included in the model as a part of the error terms as shown in equation 8 .

$$
Y_{i t}=\beta_{0}+\beta_{1} x_{i t}+v_{i t}
$$

Where $v_{i t}=\alpha_{i}+\varepsilon_{i t}, \alpha_{i}$ is time-invariant or heterogeneity variable, and $\varepsilon_{i t}$ is error term. Assuming the expected value is zero for each component, the variance of $\operatorname{var}\left(v_{i t}\right)=\operatorname{var}\left(\alpha_{i}\right)+\operatorname{var}\left(\varepsilon_{i t}\right)$, but $\operatorname{cov}\left(\alpha_{i}, \varepsilon_{i t}\right)$ is zero. If $\operatorname{var}\left(\alpha_{i}\right)>\operatorname{var}\left(\varepsilon_{i t}\right)$, Random Effect model is recommended whereas if $\operatorname{var}\left(\alpha_{i}\right)<\operatorname{var}\left(\varepsilon_{i t}\right)$, Fixed Effect Model is recommended. The Fixed Effect model makes two important assumptions about time invariant/heterogeneity/unobserved individual characteristics. The first one is time-invariant variables may have an impact of explanatory and dependent variables. Therefore, the Fixed Effect model examines the relationship of dependent and explanatory variables within a country by removing and controlling time-invariant individual characteristics in order to capture the net effect of explanatory variables. The second assumption is that timeinvariant variables are not correlated across countries and unique to each country so that error terms are also uncorrelated across countries. If these two assumptions are failed, the Random Effect model is preferable. The Hausman test is an important test to choose whether fixed or random model.

\section{Econometrics Result and Analysis}

On the basis of static panel data model with different estimation methods, this section of the study present the three major parts of econometric results such as descriptive analysis, econometric analysis, and post estimation diagnostic test. Let us see turn by turn.

\subsection{Descriptive statistics and Analysis}

Table 2 gives a summary of descriptive statistics of central tendency and measure of variability. The mean value indicates the average value of each variable in the overall model. The distribution of data around the average value can also be captured by the standard deviation that shows the closeness of data to mean value over the reference period of 1996- 2010 On top of this, the range also gives some clue about the spread of data by measuring the difference between the maximum and minimum values in each different model.

Table 2: - Descriptive statistics 


\begin{tabular}{|c|c|c|c|c|c|c|c|}
\hline $\begin{array}{l}\text { - xtsum } \\
\text { variable }\end{array}$ & kf inf & $\begin{array}{c}\text { fdp } \text { tg } f x \\
\text { Mean }\end{array}$ & $\begin{array}{l}\text { cpc sqCC } \\
\text { std. Dev. }\end{array}$ & $\begin{array}{r}\text { govregind } \\
\text { Min }\end{array}$ & $\begin{array}{l}\text { isdef polit } \\
\operatorname{Max}\end{array}$ & $\begin{array}{l}f i \\
\text { obser }\end{array}$ & ons \\
\hline kf & $\begin{array}{l}\text { overall } \\
\text { between } \\
\text { within }\end{array}$ & 90.83867 & $\begin{array}{r}867.801 \\
237.8491 \\
840.9573\end{array}$ & $\begin{array}{r}-2490 \\
-211.8867 \\
-2746.948\end{array}$ & $\begin{array}{r}4120 \\
347.7867 \\
3863.052\end{array}$ & $\begin{array}{l}N= \\
n= \\
T=\end{array}$ & $\begin{array}{l}75 \\
15 \\
15\end{array}$ \\
\hline inf & $\begin{array}{l}\text { overall } \\
\text { between } \\
\text { within }\end{array}$ & 8.576427 & $\begin{array}{r}6.09996 \\
2.355146 \\
5.720123\end{array}$ & $\begin{array}{r}6.2742 \\
-2.172133 \\
-691573\end{array}$ & $\begin{array}{r}31.1 \\
12.468 \\
27.20843\end{array}$ & $\begin{array}{l}\mathbf{N}= \\
\mathrm{n}= \\
\mathbf{T}=\end{array}$ & $\begin{array}{l}75 \\
15 \\
15\end{array}$ \\
\hline gdp & $\begin{array}{l}\text { overall } \\
\text { between } \\
\text { within }\end{array}$ & $7.78 e+09$ & $\begin{array}{l}6.03 e+09 \\
6: 211 e+09 \\
2: 25 e+09\end{array}$ & $\begin{array}{l}6.90 e+08 \\
7: 88 e+08 \\
3: 25 e+09\end{array}$ & $\begin{array}{l}2: 00 e+10 \\
1: 46 e+10 \\
1: 46 e+10\end{array}$ & $\begin{array}{l}\mathbf{N}= \\
\mathbf{n}= \\
\stackrel{T}{=}\end{array}$ & $\begin{array}{l}75 \\
15 \\
15\end{array}$ \\
\hline fdi & $\begin{array}{l}\text { overajl } \\
\text { between } \\
\text { within }\end{array}$ & $2.15 e+08$ & $\begin{array}{l}3.03 e+08 \\
2: 43 e+08 \\
2.09 e+08\end{array}$ & $\begin{array}{r}1338219 \\
-1.98 \mathrm{e}+08\end{array}$ & $\begin{array}{l}1.38 e+09 \\
5: 63 e+08 \\
1.03 e+09\end{array}$ & $\begin{array}{l}\mathbf{N}= \\
\mathrm{n}= \\
\mathbf{T}=\end{array}$ & $\begin{array}{l}75 \\
5 \\
15\end{array}$ \\
\hline tg & $\begin{array}{l}\text { overall } \\
\text { between } \\
\text { within }\end{array}$ & $8.64 e+08$ & $\begin{array}{l}9.08 e+08 \\
4: 96 e+08 \\
7: 91 e+08\end{array}$ & $\begin{array}{r}6.43 e+07 \\
3: 37 e+08 \\
-5.86 e+07\end{array}$ & $\begin{array}{l}5.78 e+09 \\
1: 577 e+09 \\
5: 07 e+09\end{array}$ & $\begin{array}{l}\mathbf{N}= \\
\mathrm{n}= \\
\mathbf{T}=\end{array}$ & $\begin{array}{l}75 \\
15 \\
15\end{array}$ \\
\hline$f x$ & $\begin{array}{l}\text { overall } \\
\text { between } \\
\text { within }\end{array}$ & 814.7547 & $\begin{array}{l}584: 5303 \\
595: 9323 \\
231: 7933\end{array}$ & $\begin{array}{l}72.706 .1 \\
206.7547\end{array}$ & $\begin{array}{r}1960 \\
1658 \\
1164.155\end{array}$ & $\begin{array}{l}\mathbf{N}= \\
\mathrm{n} \\
\mathbf{T}=\end{array}$ & $\begin{array}{l}75 \\
5 \\
15\end{array}$ \\
\hline cpc & $\begin{array}{l}\text { overall } \\
\text { between } \\
\text { within }\end{array}$ & .8149333 & $\begin{array}{l}: 3174577 \\
: 2417237 \\
: 2310918\end{array}$ & $\begin{array}{r}.5-144 \\
.4413333 \\
.2336\end{array}$ & $\begin{array}{r}1.39 \\
1.075333 \\
1.3036\end{array}$ & $\begin{array}{l}\mathbf{N}= \\
\mathrm{n}= \\
\mathbf{T}=\end{array}$ & $\begin{array}{l}75 \\
15 \\
15\end{array}$ \\
\hline sqce & $\begin{array}{l}\text { overall } \\
\text { between } \\
\text { within }\end{array}$ & .763552 & $\begin{array}{r}.4094472 \\
: 3159911 \\
.294427\end{array}$ & $\begin{array}{r}30004 \\
.3284133 \\
.1258187\end{array}$ & $\begin{array}{r}179321 \\
1.171033 \\
1.639919\end{array}$ & $\begin{array}{l}\mathbf{N}= \\
\mathrm{n}= \\
\mathbf{T}=\end{array}$ & $\begin{array}{l}75 \\
5 \\
15\end{array}$ \\
\hline govreg d & $\begin{array}{l}\text { overall } \\
\text { between } \\
\text { within }\end{array}$ & 1.238533 & $\begin{array}{l}.8373828 \\
: 8447324 \\
: 3501963\end{array}$ & $\begin{array}{r}4793336 \\
.0138667\end{array}$ & 2.303867 & $\begin{array}{l}\mathbf{N}= \\
\mathrm{n}= \\
\mathbf{T}=\end{array}$ & $\begin{array}{l}75 \\
15 \\
15\end{array}$ \\
\hline fisdef & $\begin{array}{l}\text { overall } \\
\text { between } \\
\text { within }\end{array}$ & $-1.81 e+10$ & $\begin{array}{l}2.83 e+10 \\
1: 53 e+10 \\
2: 48 e+10\end{array}$ & $\begin{array}{l}-1: 39 e+11 \\
-3: 31 e+10 \\
-1: 24 e+11\end{array}$ & $\begin{array}{r}1: 76 e+10 \\
-1: 98 e+09 \\
3: 19 e+10\end{array}$ & $\begin{array}{l}\mathbf{N}= \\
\mathbf{n}= \\
\stackrel{T}{=}\end{array}$ & $\begin{array}{l}75 \\
5 \\
15\end{array}$ \\
\hline polityz & $\begin{array}{l}\text { overall } \\
\text { between } \\
\text { within }\end{array}$ & -.4133333 & $\begin{array}{r}4 \cdot 20133 \\
3.252828 \\
3.011988\end{array}$ & $\begin{array}{r}-4.066666 \\
-9.013333\end{array}$ & $\begin{array}{r}3.8 \\
3.986667\end{array}$ & $\begin{array}{l}\mathbf{N}= \\
\mathbf{n}= \\
\stackrel{T}{=}\end{array}$ & $\begin{array}{l}75 \\
5 \\
15\end{array}$ \\
\hline$s f i$ & $\begin{array}{l}\text { overajl } \\
\text { between } \\
\text { within }\end{array}$ & 17.33333 & $\begin{array}{l}3.688306 \\
3: 456716 \\
1: 978716\end{array}$ & $\begin{array}{r}13.46667 \\
13: 93333\end{array}$ & $\begin{array}{r}20 \\
20.86667 \\
20: 46667\end{array}$ & $\begin{array}{l}\mathbf{N}= \\
\mathrm{n}= \\
\mathbf{T}=\end{array}$ & $\begin{array}{l}75 \\
15 \\
15\end{array}$ \\
\hline
\end{tabular}

Source: - Author computations using SATAT

N.B: - Kf is capital flight, Inf is inflation rate, gdp is Gross Domestic Product, fx is foreign exchange rate, cpc is corruption index, sqcc is the square of corruption index, govregrd is an aggregate index of government and regulatory quality, fisdef is fiscal deficit, polity2 is index of political instability, and sfi is an index of state fragility.

Specifically, the heterogeneity of capital flight across EAC countries varies with countries. Kenya in this regard has a highest variation against the mean value of capital flight while Tanzania has the lowest variation of capital flight that moves around the mean (Figure 1). Note that 1 denotes Burundi, 2 for Kenya, 3 for Tanzania, 4 for Rwanda and 5 for Uganda.

Figure 1: - Heterogeneity across countries

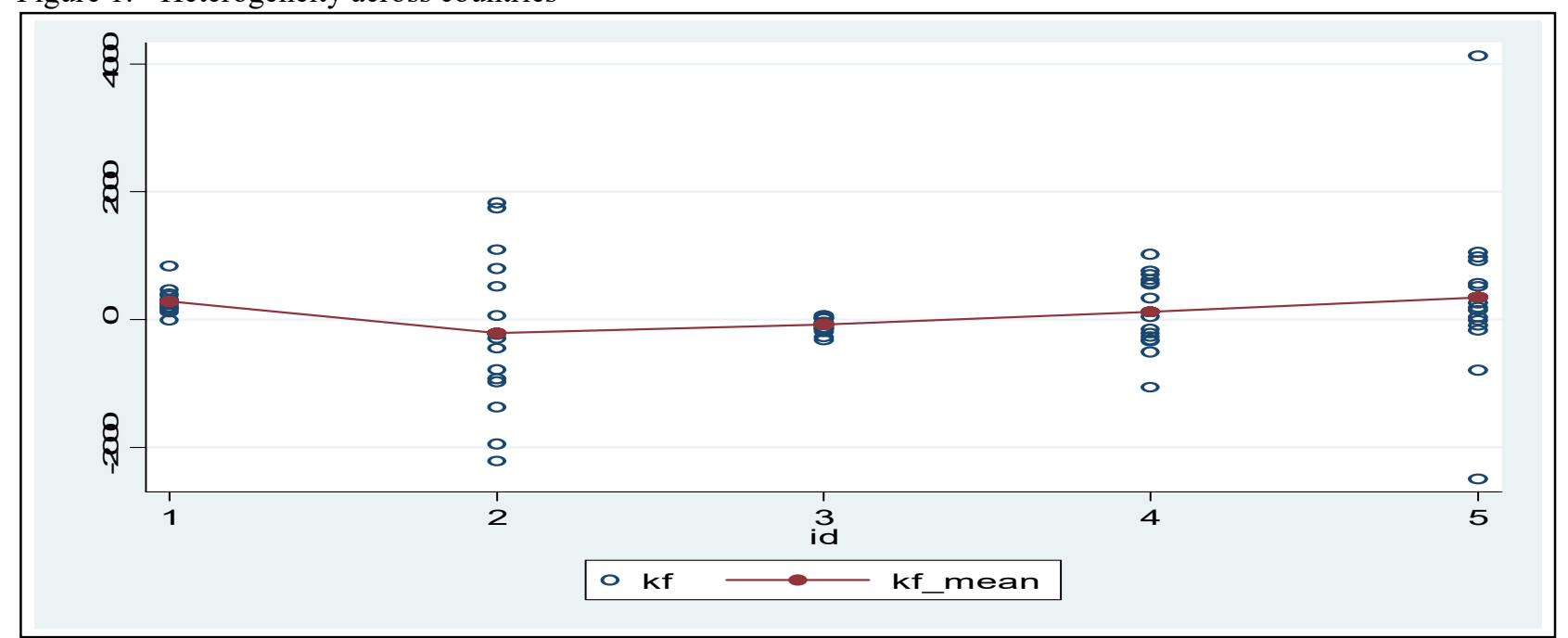

Source: - Source: - Author computations using SATAT

In the same manner, the heterogeneity of capital flight across years also provides the entire distribution of capital flight data around the mean overtime. It indicates that capital flight in EAC has been spread with an increasing variation since 2000, where EAC was reformed in the recent context. 
Figure 2: - Heterogeneity across years

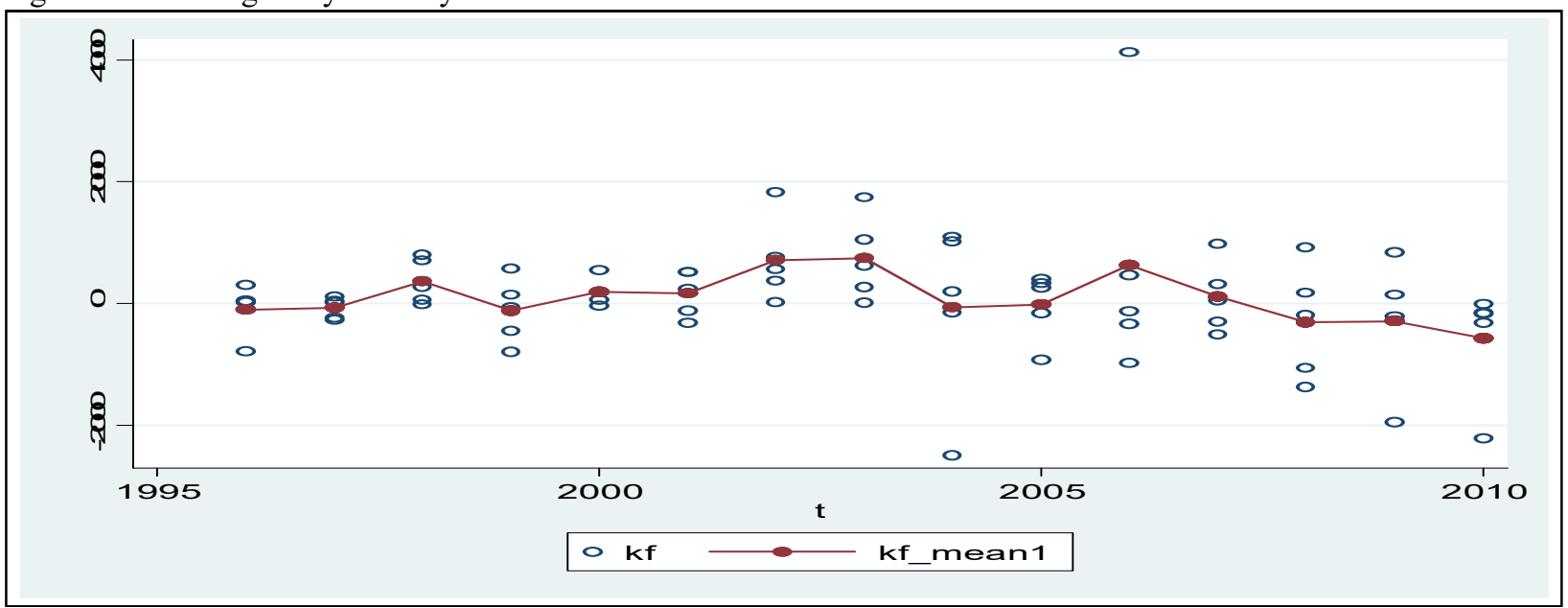

Source: - Source: - Author computations using SATAT

\subsection{Panel Model Econometrics Results}

The macro econometric panel model here gives a result of both fixed effect and random effect models. The between the method for the fixed effect model is not included here since it is highly affected by multicollinearity problem and the system failed to work. On top of this, the study finds that heteroskedasticity and autocorrelation are a severe problem associated with each panel model. Therefore, the study uses and presents the robust model after controlling both heteroskedasticity and autocorrelation.

\section{Fixed Effect Model of Capital Flight:}

Table 3 gives us fixed effect (within) regression result. From the result, we can understand that the $\mathrm{R}^{2}$ for within, between, and overall effect model is 36 percent, 33 percent and 5percent, respectively. As $\mathrm{R}^{2}$ for the within effect is the highest among them, it tells that individual and short run effect is more important than time and long run effect in EAC capital flight. The corr $\left(\mathrm{u}_{-1}, \mathrm{xb}\right)=-0.9886$ shows that the negative correlation between error terms and explanatory variable and this ensures the assumption of fixed effects model in this regard. All explanatory variables are jointly statistically significant at 5 percent level of significance and adequate enough to explain change in capital flight.

Table 3:- Regression Result of Within Effect Method

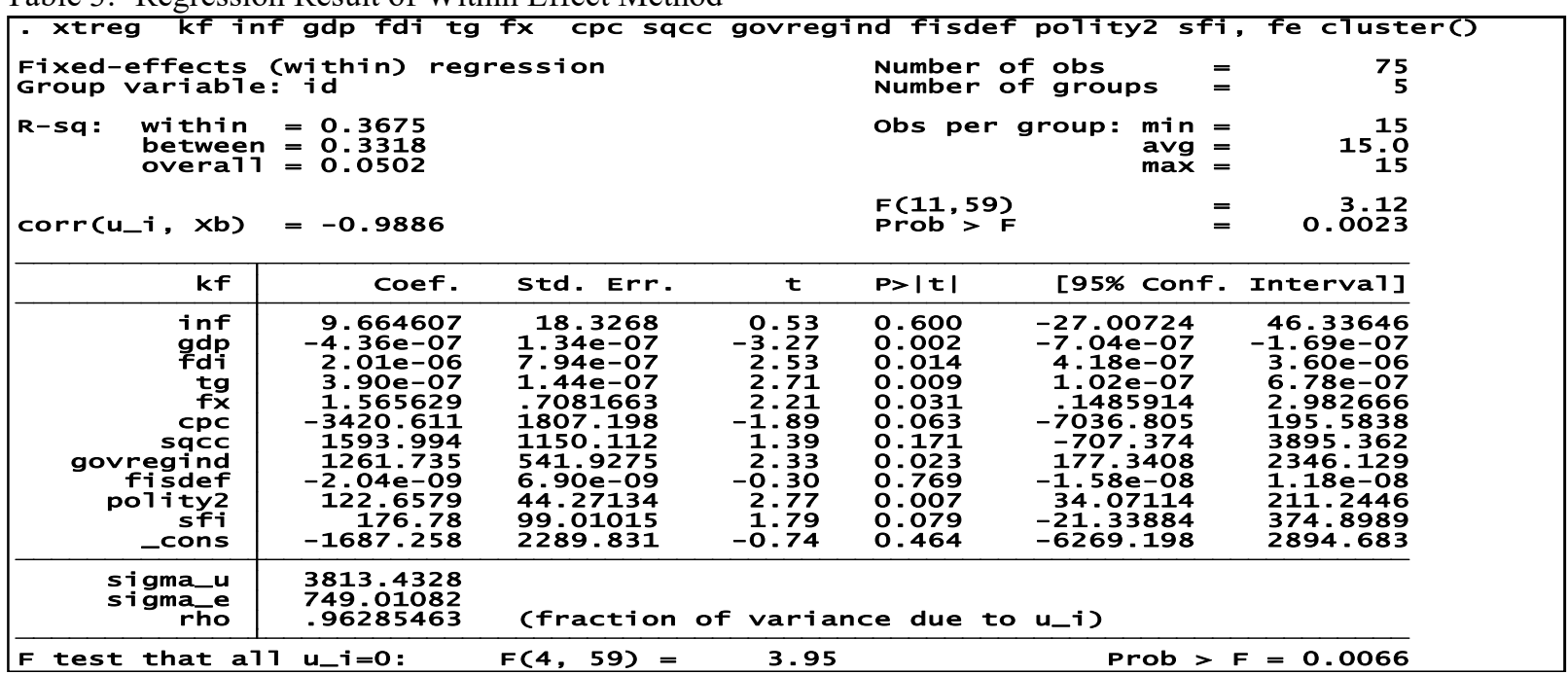

Source: - Regression result based on within effect method

Except inflation rate, fiscal deficit and the square value corruption index, all explanatory variables are statistically significant at 1 percent and 5 percent level of significance and capable of explaining change in capital flight in EAC member countries. We also learn that an increase in the size of the economy in terms of GDP puts on a negative implication for an illegal flow of capital from the EAC countries, attributing to the fact that capital holders prefer to invest home in order to reap remarkable profits following sustainable economic growth. Both the inflow of FDI and total grant positively contribute to capital flight from the Community member countries, reflecting foreign resources are highly associated with capital flight and widening the bribery circumstances that 
pushes scarce capital to go out from countries. On top of foreign resource, exchange rate also one the influencing factor that the capital owners taking into account where they allocate their capital at hand. The fixed model indicates that an increase in foreign exchange rate leads to reducing the value of domestic currency and encouraging holding capital in terms of foreign currency. In the presence of scarce foreign currency, capital owners then move their capital out of the country at the situation of currency devaluation. This enables us to conclude that capital flight and foreign exchange rate have a positive relationship.

The various dimensions of governance quality also reveal that capital flight is also explained by poor regulatory and government performance as well as the existence of recurrent political instability. Indicators of an aggregate index of regulatory quality and government effectiveness and an index of political instability positively influence an illicit capital flight. This is definitely right in a case of poor countries as they have poor governance qualities that widely pave a way to an illegal outflow of capital. Regarding the corruption index, the existed perceived corruption does not positively contribute to capital flight, but an intensive corruption positively influences capital flight overtime, bringing a mixed sign of negative and positive depending on the level of corruption that affects capital flight overtime in the EAC member countries. The rho ${ }^{1}$ that measures the intraclass correlation shows that $96.2 \%$ of the variance is due to difference across panels, heterogeneity effect. This indicates that each member of EAC country has no similar time invariant characteristics so that they are well considered for policy prescription.

In order to capture the effect of individual country on capital flight, it is more suitable to employ LSDV method. The model introduces constant terms and creates dummy variables for all countries except Burundi. Cross section 1 for Burundi, 2 stands for Kenya, 3 for Rwanda, 4 for Tanzania and 5 for Uganda. Table 4 gives details results in this regard by keeping the coefficients and level of statistical significance the same for all explanatory variables as the within method gives earlier. Country-specific characteristics are statistically significant and have positive impacts on capital flight, reflecting they are strong enough to explain change in capital flight.

Table 4: - Regression Result of Lease Square Dummy Variable Method

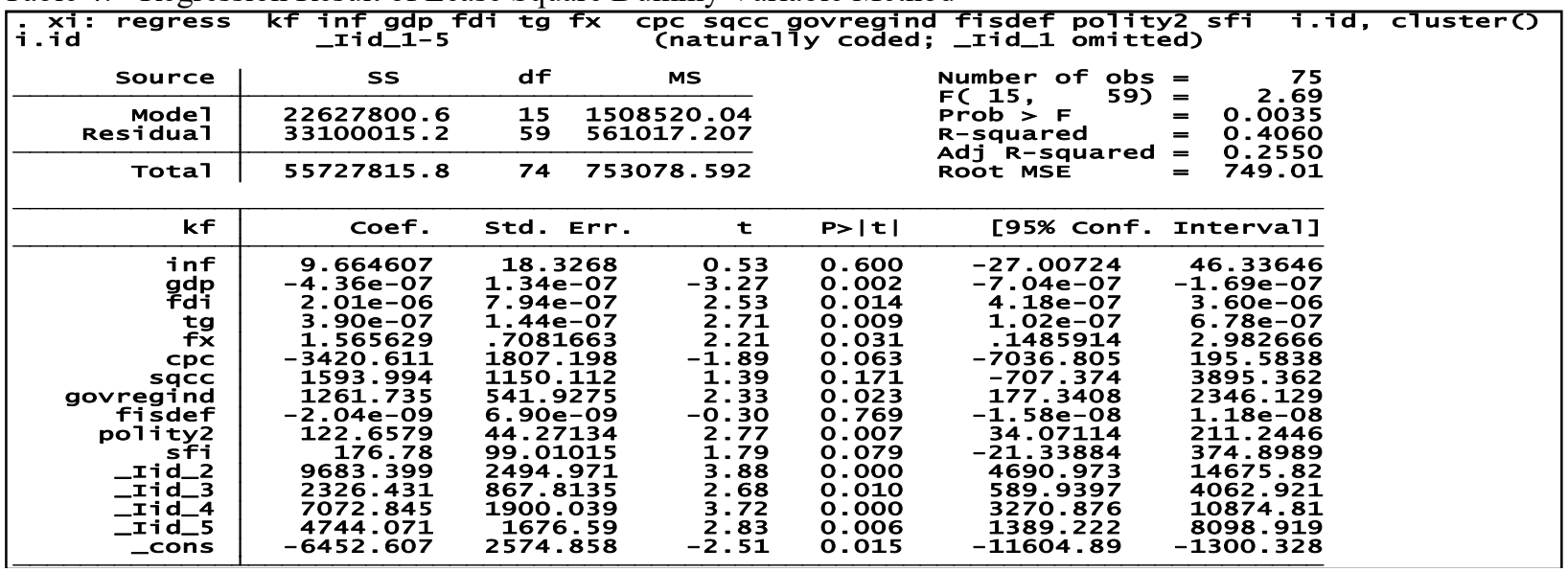

Source: - Regression result based on within effect method

Random Effect Model of Capital Flight: -

It captures information over time and across countries, so that the coefficients are used to predict changes over time and explain countries difference, including both within individual effects and between individual effects. This implies that the data represents the average effects of independent variables over capital flight. In this regard, the average effects of total grants and fiscal deficit are statistically significant and positively contribute to an illegal flow of capital flow from the ECA. The residual variable is assumed to be uncorrelated with explanatory variables, indicating difference across units is uncorrelated with explanatory variables. The Wald chi2 $=20.66$ with a probability of zero shows to test whether all the coefficients in the model are different from zero. Accordingly, it is greater than the tabulated F-test value; we reject the null hypothesis that states the entire coefficients together equal to zero. Said differently, as the probability of getting chi2 test of 20.66 is zero, this is less than 0.05 , we reject the null hypothesis. All the coefficients are different from zero. The Wald test also confirms that all explanatory variables are able to jointly and statistically explain the change in capital flight (Table 5).

Table 5: - Regression Result of Random Effect Method

$$
{ }^{1} \text { Note that } r h o=\frac{\left(\operatorname{sigma} \_u\right)^{2}}{\left(\operatorname{sigma}_{-} u\right)^{2}+\left(\operatorname{sigma} \_e\right)^{2}}, \text { Sigma_u }=\text { Standard deviation of residuals within group and Sigma_e }=\text { Standard }
$$

deviation of residuals of overall model. 


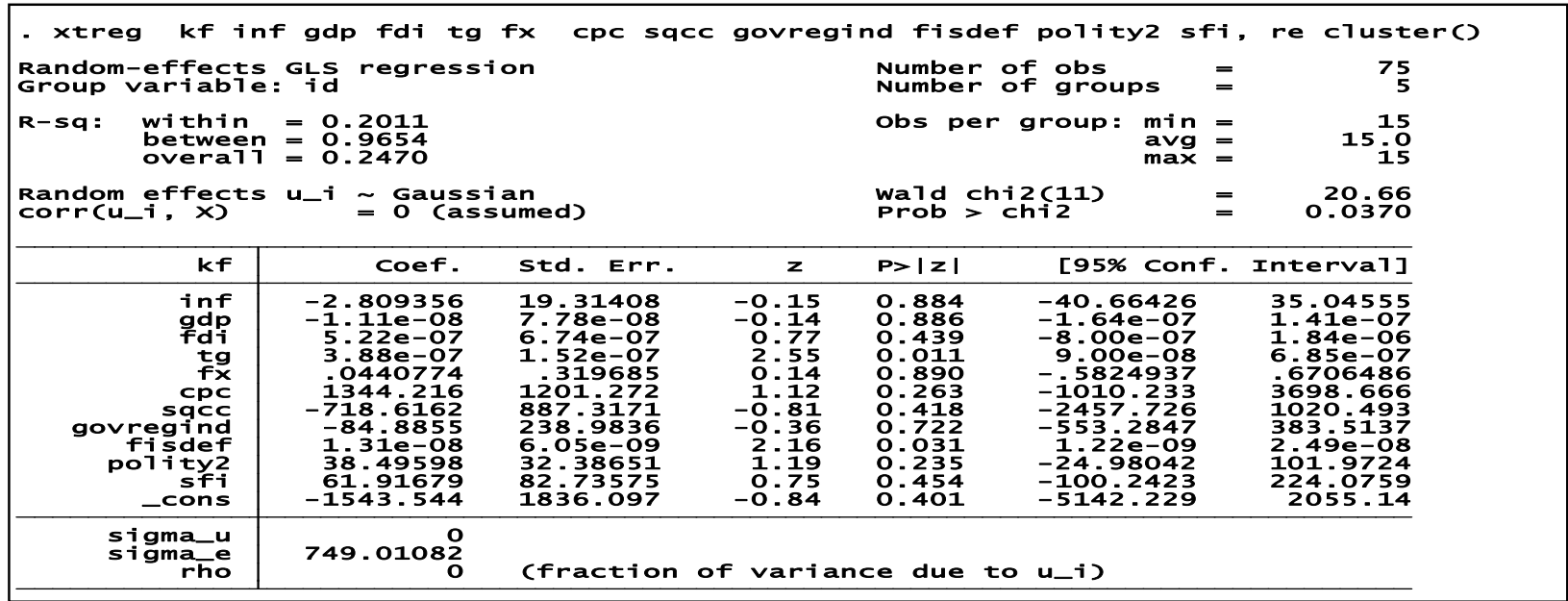

Source: - Regression result based on within effect method

We can also understand that the $\mathrm{R}^{2}$ for within, between, and overall effect model is 20 percent, 96 percent, and 24 percent, respectively. As $\mathrm{R}^{2}$ for the between effect is highest, it tells that the time effect is more important than individual effect, we can say that the long run effect is more important than short run effect. Controlling the effect of heterogeneity and autocorrelation, the rho shows that zero percent of variance is due to difference across panels, heterogeneity effect. Note that 'rho' is known as the interaclass correlation.

\section{Which One Do We Choose? Fixed or Random}

To decide between fixed or random effects, we can run a Hausman test where the null hypothesis is that the preferred model is Random Effect vs. the alternative the Fixed Effects. It is basically tests whether the unique errors are correlated with the regressors; the null hypothesis is they are not. As mentioned above, random effects coefficients have a dual nature: They simultaneously explain change over time and the cross-sectional differences among units. The implicit assumption is that both types of effects are the same. We test this assumption using the Hausman test. The Hausman test checks a more efficient model against a less efficient. If the prob. $>$ chi $^{2}$ is less than 0.05 , it is statistically significant so that we need to use the Fixed Model. Thus, we reject the null hypothesis states that fixed effects and random effects coefficients are significantly same, we prefer to pick fixed effect model. Table 6: Hausman Test

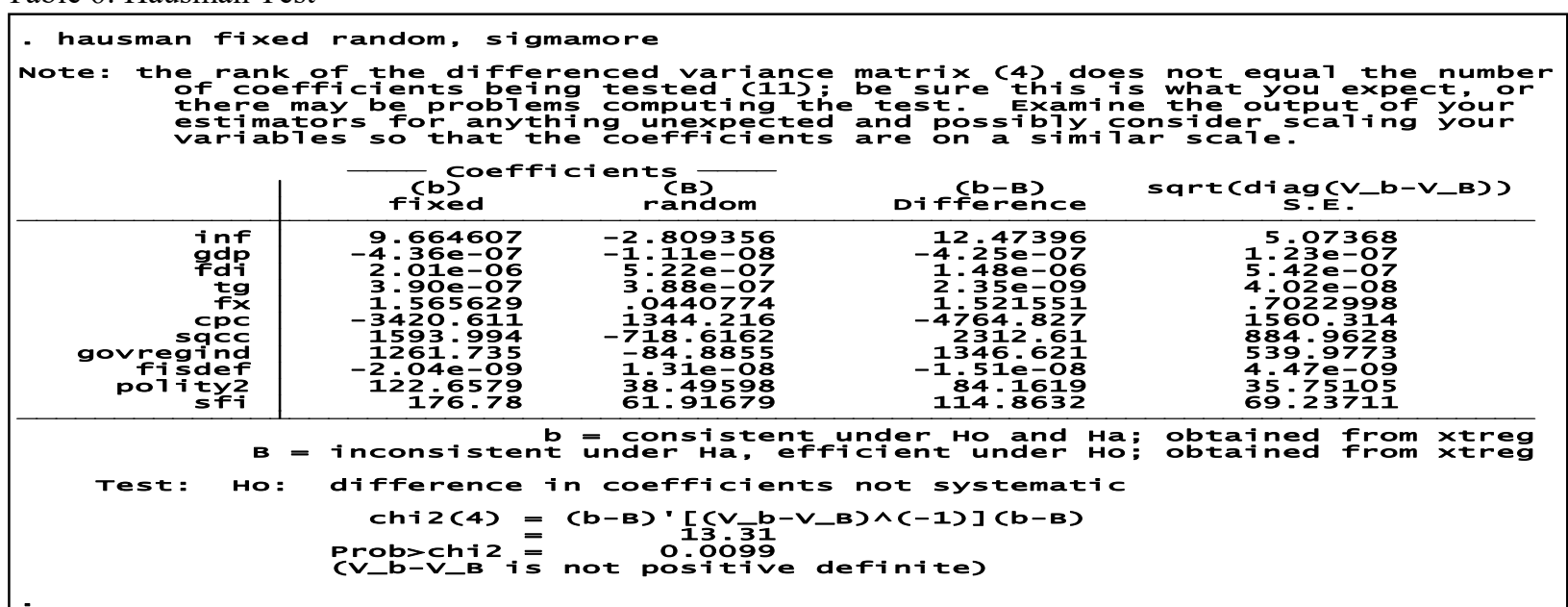

\section{Source: - Hausman Test result}

Comparing these coefficients to the fixed effects coefficients in the Hausman output, we can identify variables responsible for the some major differences. We could also estimate the two types of effects (over time and across units) separately in a single random effects model using the same kind of person-specific mean variables and meandifferenced variables that we created when examining fixed effects models (this is only done for time-varying variables). Examining the coefficients, we might suspect that variables that have a positive difference are responsible for the difference $(b-B)$.

\section{Other Diagnostics Tests:}

No research can conclude the results of regression analysis without considering a range of diagnostic tests for heteroskedasticity, autocorrelation, normality, goodness-to-fit and the like. The diagnostic tests assist to detect the 
inadequacy of the model and identify the strengths and weakness of the model. They also reduce the probability of wrongly rejecting or accepting the null hypothesis. One of the interesting points of diagnostic test is to check whether time fixed effects are required or not. The null hypothesis testing in this regard states that time fixed effects are not needed if the dummies for all years are jointly equal to zero. Accordingly, we accept the null hypothesis as the probability of F-test is 0.4898 when we use the command testparm (Annex 2). On the other hand, the Breusch-Pagan Lagrange multiplier also indicates that we accept the null hypothesis and suggest that random effect model is not suitable for our cases, reflecting the inexistence of significant difference across countries (Annex 3). The Breusch-Pagan Lagrange multiplier test is also important to run testing for cross-sectional dependence or contemporaneous correlation. Most of macro panel data faces such cross-sectional dependence, leading to bias in test results. Accordingly, we accept the null hypothesis that states residuals across countries are not correlated so that there no cross-sectional dependence (Annex 4). The Pasaran test also confirms the same conclusion about the inexistence of cross-sectional dependence (Annex 5).

\section{Conclusion and Policy Implications}

The East African Community is one of the emerging and encouraging economic integrations with the objective of political federation. However, it is highly challenged by the existing capital flight in weakening capital formation and intensifies capital scarcity. This puts a negative pressure on economic growth and economic transformation process. The community has lost a huge amount of foreign capital in last decades. Uganda, for instance, has lost USD 8.8 billion and became one of the top ten LDC countries that illegally export capital in 1990-2008. Taking only Swiss Banks, the EAC countries have lost USD 1.3 billion in terms of tax haven. On top of this, the community has been poor in all dimensions of governance indicators- severe corruption, poor governance, weak regulatory performance, political instability and the like.

In order to address the critical causes of such an illegal form of capital flight, the study uses a robust panel model based on data for the period 1996- 2010. After controlling the effect of heteroskedasticity, autocorrelation, and cross-sectional dependence, the robust panel model, generate very conclusive results in figuring out the statistically significant political economic and institutional factors. Accordingly, all explanatory variables - GDP, foreign direct investment and grant, exchange rate, an aggregate index of regulator quality and governance effectiveness, political instability, state fragile index, and corruption index are statistically significant at 1 percent and 5 percent level of significance and capable of explaining change in capital flight in EAC member countries. However, inflation rate, fiscal deficit and the corruption intensity index are not statistically significant in order to explain capital flight in the EAC.

It also indicates that a remarkable economic growth, as measured by GDP, plays a pivotal role in curbing an illegal flow of capital from the EAC countries. Otherwise, domestic investors opt to put and invest their capital in the place where there is stable economic growth. On the same note, the inflow of FDI and total grant aggravate the outflow of capital illegally on account of discriminatory policies and due to lack of enabling investment climate for local investors. Exchange rate also one the influencing factor as investors illegally move their capital out of the country at the situation of currency devaluation. On top of economic factors, both institutional and political factors are important in explaining capital flight and should not be ignored at all. The absence of effective governance, regulatory quality, political stability and state solidarity are statistically significant and aggravate an illicit outflow of capital from the Community. However, the impacts of corruption depend on the intensity of corruption level, implying the existed perceived corruption does not positively contribute to capital flight, but an intensive corruption index, as measured by square of corruption index, positively influences capital flight overtime.

The findings of the study provide a conclusive policy implication for the Community in order to build up capital formation. The first implication is subject to economic factors. The member governments of Community need to devise a mechanism of enhancing the effectiveness and efficiency of foreign resource of grant and direct investment. Otherwise, it aggravates capital outflow in an illegal way at the cost of domestic economy. The macroeconomic policy towards foreign exchange rate has also a negative repercussion on capital flight in the situation of devaluing exchange rate. Therefore, governments also should reorient devaluation policy with rescuing countries from capital flight. Besides, the negative relationship between GDP and capital flight implies that both stable economic growth rate and remarkable GDP performance allow generating attractive investment environment and enabling to reduce capital outflow. The second policy implication is linked with political and institutional factor in the context of good governance. The respective government in the Community puts their unreserved endeavors in order to build political stability, state solidarity, and good governance.

\section{Reference}

Abdilahi and Bernard (2011), On the Causes of Capital Flight from Sub-Saharan Africa, University of Manchester,

Acemoglu Daron, Simon J., James R., and Yunyong T,. (2003), Institutional causes, macroeconomic symptoms: volatility, crises and growth, Journal of Monetary Economics, 50(1): 49-123. 
Ajayi (1992), an Economic Analysis of Capital Flight from Nigeria, World Bank, Working Paper 993

Bhagwati (1964), On the Under invoicing Imports, Bulletin of the Oxford University, Institute of Economics and Statistics, Vol. 26, Oxford, pp. 389-397

Boyrie (2010), Determinants of Capital Flight and Capital Movement through Trade Mispricing: The African Case, African Journal of Accounting, Economics, Vol. 6.

Cerra Valerie, Meenakshi Rishi, and Sweta Saxena, (2008), Robbing the Riches: Capital Flight, Institutions, and Instability, IMF Working Paper 05/199.

Cerven (2006), The Measurement of Capital Flight and Its Impact on long-term Economic Growth: Empirical Evidence from a cross-section of Countries, University Bratislava.

Collier (2006), African growth: why big push? Journal of African Economies, (15), Supplement 2, 188.211

Collier, P., Hoeffler, A., Pattilo, C. (2001), Flight capital as a portfolio choice, The World Bank Economic Review 15 (1), 55e80.

Collier, Hoeffler, and Pattillo, (2004), Aid and Capital Flight, Oxford University: Centre for the Study of African Economies.

Dooley (1988), Capital Flight: A Response to Differences in Financial Risks, IMF Staff Papers, Vol. 35, No. 3, pp 422-36 (Washington: International Monetary Fund).

Dornbusch (1990), Policies to Move from Stabilization to growth, Proceedings of the World Bank Annual Conference on Development Economics

EAC (2011), Deepening And Accelerating Integration, EAC Development Strategy (2011/12 - 2015/16), Kenya, Nairobi.

Epstein (2005), Capital Flight and Capital Controls in Developing Countries, Northampton, UK: Edward Elgar Publishing Limited.

Forgham (2008), capital flight, measurement and economic growth in Cameroon: an econometrics investigation", international review of business research paper, vol. 4, no. 2

Hermes and Lensik, (2001), Capital Flight and the Uncertainty of Government Policies, Economics Letters, 71 (3)

Lensink, R., Hermes, N. \& M urinde, V . (2000) Capital flight and political risk, Journal of International Money and Finance, 19, pp. $73-92$.

Morgan Guaranty (1988), LDC Debt Reduction: A Critical Appraisal, World Financial Markets, 7.

Ndiaye (2009), capital flight and its determinants in the Franco Zone, African Economic Research Consortium RP 215.

Ndikumana and Boyce, (2003), Public Debts and Private Assets: Explaining Capital Flight from Sub-Saharan African Countries, World Development 31 (1).

Nyoni, (2000), Capital Flight from Tanzania, in Ajayi, Ibi and Mohsin Khan (Eds.) External Debt and Capital Flight in Sub-Saharan Africa, the IMF Institute

Schneider (2001), Measuring Capital Flight: Estimates and Interpretations, London: Overseas Development Institute.

Seung, (2010), Institutional Quality, Capital Flight And Capital Flows, The Korean Economic Review, Volume 26, Number 1, Summer 2010

Sheets (1995), Capital fight from the countries in transition: some theory and empirical evidence, International Finance Discussion Pap er No. 514.

Thomas (2010), Institutions and Capital Flight in the Global Economic Crisis, Department of Government, Cornell University pepinsky@cornell.edu

World Bank (2013), The Worldwide Governance Indicators, www.govindicators.org 
Annex I: Explanation of Variables and Sources

\begin{tabular}{|c|c|c|}
\hline Variables & Explanation & Sources \\
\hline $\mathrm{kf}$ & $\begin{array}{l}\text { Capital flight calculated based on the Residual Method. } \\
\text { It is also expressed in terms of constant } 2010 \text { USD } \\
\text { dollars }\end{array}$ & $\begin{array}{l}\text { James K. Boyce and Leonce } \\
\text { Ndikumana, Updated estimates, 1970- } \\
\text { 2010, Political Economy Research } \\
\text { Institute, PERI, University of } \\
\text { Massachusetts, 2012. }\end{array}$ \\
\hline gdp & $\begin{array}{l}\text { Gross Domestic Product expressed in terms of constant } \\
2010 \text { USD dollar. }\end{array}$ & $\begin{array}{l}\text { WB (2011), World Development } \\
\text { Indicator online data base. }\end{array}$ \\
\hline fdi & $\begin{array}{l}\text { Foreign direct investment, net inflows in reporting } \\
\text { economy. }\end{array}$ & $\begin{array}{l}\text { United Nations Conference on Trade } \\
\text { and Development, Foreign Direct } \\
\text { Investment Online database. }\end{array}$ \\
\hline $\operatorname{tg}$ & Total Grants, including technical cooperation & $\begin{array}{l}\text { United Nations Conference on Trade } \\
\text { and Development, Foreign Direct } \\
\text { Investment Online database. }\end{array}$ \\
\hline fx & Official Exchange Rate & IMF, online data base \\
\hline cpc & $\begin{array}{l}\text { Reflects perceptions of the extent to which public power } \\
\text { is exercised for private gain, including both petty and } \\
\text { grand forms of corruption, as well as "capture" of the } \\
\text { state by elites and private interests. This index is } \\
\text { rescaled to have higher values shows greater corruption } \\
\text { so that Corruption index }=\text { (Corruption control index *- } \\
\text { 1) }\end{array}$ & $\begin{array}{l}\text { The Worldwide Governance Indicators, } \\
2013 \text { updates, aggregator indicators of } \\
\text { governance 1996-2012 }\end{array}$ \\
\hline govregind & $\begin{array}{l}\text { This is an index of aggregating both governance } \\
\text { effectiveness and regulatory quality. An index of } \\
\text { governance effectiveness reflects perceptions of the } \\
\text { quality of public services, civil service, policy } \\
\text { formulation and implementation, credibility of the } \\
\text { government and degree of its independence from } \\
\text { political pressures. An index of regulatory quality index } \\
\text { on the other hand reflects perceptions of the ability of } \\
\text { the government to formulate and implement sound } \\
\text { policies and regulations that allow private sector } \\
\text { development. This index is rescaled as (effectiveness } \\
\text { and regulatory quality indices *-1) to have higher values } \\
\text { shows greater corruption. }\end{array}$ & $\begin{array}{l}\text { The Worldwide Governance Indicators, } \\
2013 \text { updates, aggregator indicators of } \\
\text { governance 1996-2012 }\end{array}$ \\
\hline fisdef & $\begin{array}{l}\text { Fiscal Deficit, the gap between total revenue and total } \\
\text { government expenditure }\end{array}$ & IMF, online data base \\
\hline polity 2 & $\begin{array}{l}\text { This variable is a modified version of the POLITY } \\
\text { variable added in order to facilitate the use of the } \\
\text { POLITY regime measure in time-series analyses. It } \\
\text { measures the combined index of autocracy and } \\
\text { democracy level of a given country. }\end{array}$ & $\begin{array}{l}\text { POLITYTM IV PROJECT, 1800-2012, } \\
\text { Dataset Users' Manual, Monty G. } \\
\text { Marshall Center for Systemic Peace and } \\
\text { Societal-Systems Research Inc, Ted } \\
\text { Robert Gurr University of Maryland } \\
\text { (emeritus), and Keith Jaggers Colorado } \\
\text { State University (2013) }\end{array}$ \\
\hline sfi & $\begin{array}{l}\text { It measures the fragility of States in the area of } \\
\text { economic Effectiveness, economic Legitimacy } \\
\text { effectiveness, social Legitimacy, and political } \\
\text { Legitimacy. }\end{array}$ & $\begin{array}{l}\text { Global Report 2011, Conflict, } \\
\text { Governance, and State Fragility and } \\
\text { Monty G. Marshall Benjamin R. Cole }\end{array}$ \\
\hline
\end{tabular}




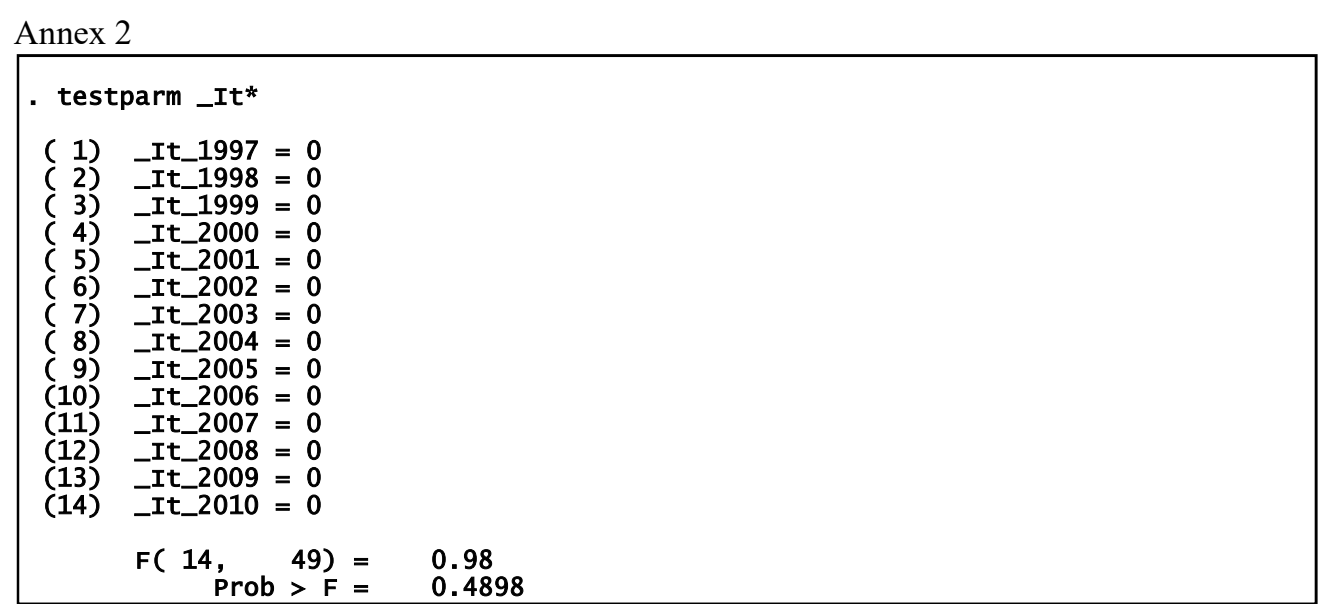

Annex 3

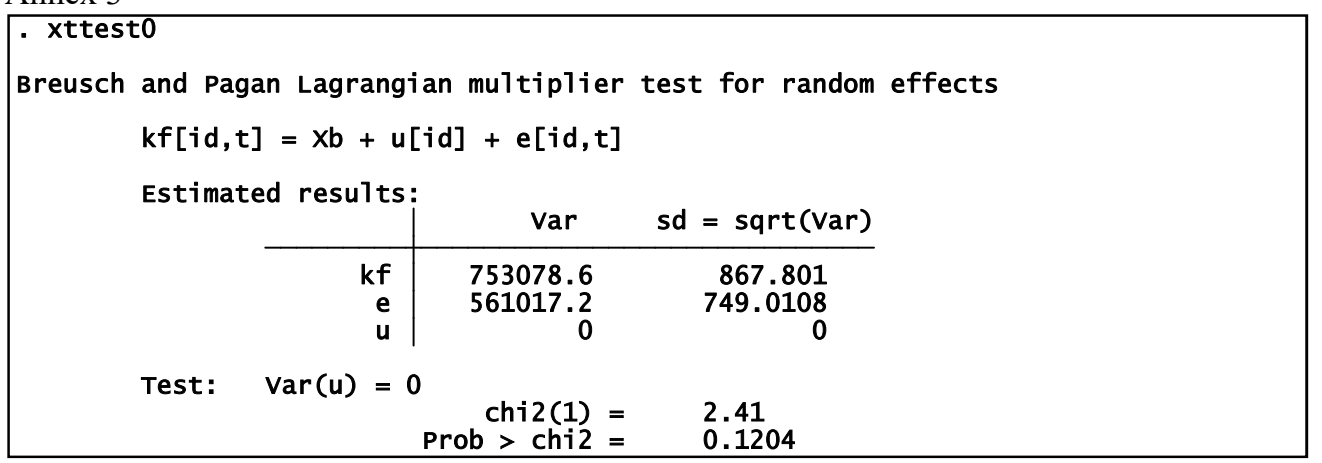

Annex 4

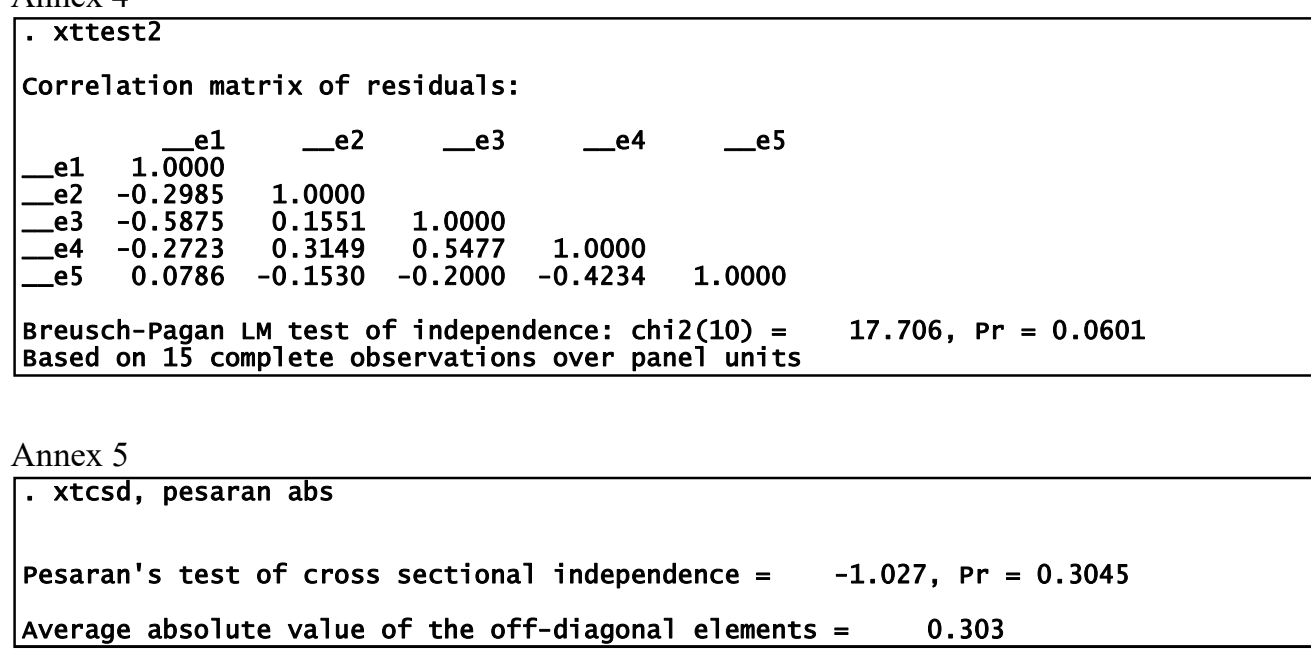

